University of Nebraska - Lincoln

DigitalCommons@University of Nebraska - Lincoln

Faculty Papers and Publications in Animal

Science

Animal Science Department

1980

\title{
Effects of Microbial Feed Additives on Performance of Starter and Growing-Finishing Pigs
}

\author{
D. S. Pollmann \\ University of Nebraska-Lincoln \\ D. M. Danielson \\ University of Nebraska-Lincoln \\ E. R. Peo, Jr. \\ University of Nebraska-Lincoln
}

Follow this and additional works at: https://digitalcommons.unl.edu/animalscifacpub

Part of the Animal Sciences Commons

Pollmann, D. S.; Danielson, D. M.; and Peo, Jr., E. R., "Effects of Microbial Feed Additives on Performance of Starter and Growing-Finishing Pigs" (1980). Faculty Papers and Publications in Animal Science. 650.

https://digitalcommons.unl.edu/animalscifacpub/650

This Article is brought to you for free and open access by the Animal Science Department at DigitalCommons@University of Nebraska - Lincoln. It has been accepted for inclusion in Faculty Papers and Publications in Animal Science by an authorized administrator of DigitalCommons@University of Nebraska - Lincoln. 


\title{
EFFECTS OF MICROBIAL FEED ADDITIVES ON PERFORMANCE OF STARTER AND GROWING-FINISHING PIGS ${ }^{1}$
}

\author{
D. S. Pollmann, D. M. Danielson and E. R. Peo, Jr. \\ University of Nebraska ${ }^{2}$, North Platte 69101
}

\begin{abstract}
Summary
Three trials were conducted to evaluate the effect of lactic acid-producing microbial feed additives (Probiotics) on performance of starting and growing-finishing pigs. Two commercially available probiotics, Probios ( $L$. acidopbilus) and Feed-Mate 68 (Streptococcus faecium type Cernelle 68), were used. In the first of two starter trials, 192 crossbred pigs (initial weight $7 \mathrm{~kg}$ ) were used in a $2 \times 4$ factorial arrangement of treatments, with Probios and antibiotics (ASP-250, lincomycin, tylosin) as the main effects. Addition of antibiotics, regardless of source, improved $(P<.05)$ average daily gain (ADG) and feed conversion (FC). ADG and FC were improved by 2.6 and $3.6 \%$, respectively, with probiotics $(\mathrm{P}<.10)$. A suggestion of an additive effect was observed for lincomycin plus Probios. In the second trial, with 224 pigs, virginiamycin was evaluated in combination with Probios, Feed-Mate 68 and DL-lactic acid. The antibiotic effect was not significant; addition of probiotic products and DL-lactic acid improved FC $(\mathrm{P}<.05)$. Probios improved ADG $9.7 \%$ and FC $4.4 \%$, while Feed-Mate 68 decreased performance. A growing-finishing trial was conducted with 144 crossbred pigs (average initial weight $34 \mathrm{~kg}$ ) to determine the effect of probiotics, lincomycin or a combination on ADG and FC of growingfinishing swine. Probiotics did not affect performance, but addition of lincomycin increased $\mathrm{ADG}$ by $3.6 \%(\mathrm{P}<.05)$ and $\mathrm{FC}$ by $2.5 \%(\mathrm{P}<.10)$.
\end{abstract}

(Key Words: Swine, Probiotics, Lactobacilli, Streptococcus faecium, Antibiotics.)

\footnotetext{
${ }^{1}$ Published as Paper No. 5880, Journal Ser., Nebraska Agr. Exp. Sta.

${ }^{2}$ Dept. of Anim. Sci. Acknowledgement is made to Debbie Koester and Alice Teter for their assistance in preparation of the manuscript.
}

\section{Introduction}

The importance of maintaining an ideal intestinal flora in swine has been recognized for many years. In the past few decades, the most common method of repressing the nondesirable microorganisms has been treatment with antibacterial agents. Since future legislation may prohibit the use of subtherapeutic levels of antibacterials, the use of probiotics as a possible alternative to antibiotics has received renewed interest.

Metchnikoff (1908) speculated on the harmful role of intestinal fermentation caused by proteolytic and putrifying organisms, noting that it can lead to autointoxication. The recommended solution was the addition of lactic acid-producing bacteria (lactobacilli) in an effort to establish a "desirable" microflora population in the intestinal tract.

Several possible modes of action for lactobacilli benefits have been suggested: (1) change in enteric flora and reduction of $E$. coli (Porter and Kenworthy, 1969; Hill et al., 1970a,b; Moon, 1975; Mitchell and Kenworthy, 1976; Muralidhara et al., 1977); (2) production of antibiotic substances (Shahani et al, 1976, 1977); (3) synthesis of lactate with concomitant reduction in intestinal $\mathrm{pH}$ (White et al., 1969; Herrick, 1972); (4) adhesion to or colonization in the digestive tract (Fuller and Brooker, 1974; Muralidhara et al., 1977) and (5) prevention of toxic amine synthesis (Hill et al., 1970a,b).

Lactobacillus therapy has been shown to help improve gain and feed efficiency in poultry (Tortuero, 1973; Fuller and Brooker, 1974) and swine (Parker, 1975; Baird, 1977; Hale and Newton, 1979). However, other researchers (Hines and Koch, 1971; Mahan and Newland, 1976; Cline et al., 1976; Holden, 1976) have observed no significant response in swine. The efficacy of lactobacillus products has not been fully elucidated. The objective of this study was to evaluate the effects of two commercially 
available lactic acid-producing bacterial feed additives (probiotics) on gains and feed conversion of starting and growing-finishing pigs.

\section{Experimental Procedure}

Starter Trials. Two trials were conducted with young swine. In the first, 192 crossbred pigs (12 pigs/treatment, two replications) approximately 4 weeks old were allotted by initial weight (average $7 \mathrm{~kg}$ ) to treatments in a 2 $\times 4$ factorial arrangement of treatments, with probiotics and antibiotics as the main effects. Probios $^{3}(750 \mathrm{mg} / \mathrm{kg})$, a commercial probiotic product, was evaluated in combination with ASP- $250^{4}$, tylosin ${ }^{5}$ or lincomycin ${ }^{6}$ in an $18 \%$ crude protein diet (table 1).

The pigs were housed in a conventional nursery with $40 \%$ slatted floors and allowed ad libitum access to water and feed. The study was

\footnotetext{
${ }^{3}$ NuLabs Division, Pioneer Hi-Bred International, Portland, OR.

${ }^{4}$ ASP-250, American Cyanamid Co., Agr. Div., Princeton, NJ.

${ }^{5}$ Tylan 10, Elanco Product Co., Division of Eli Lilly and Co., Indianapolis, IN.

${ }^{6}$ Lincomix 20, TUCO, Division of UpJohn, Kalamazoo, MI.

${ }^{7}$ Feed-Mate 68, Anchor Laboratories, Inc., Division of Phillips Roxane, Inc., St. Joseph, MO.

${ }^{8}$ Statfac, Animal Health Products, Division of Smith Kline Corp., Philadelphia, PA.
}

started on the day of weaning and terminated 30 days later.

In the second trial, another commercial probiotic product called Feed-Mate $68^{7}$, Streptococcus faecium (lactic acid-producing bacteria) Cernelle 68, was evaluated in combination with virginiamycin ${ }^{8}(110 \mathrm{mg} / \mathrm{kg})$ in a 2 $\times 4$ factorial arrangement of treatments with 224 crossbred pigs (14 pigs/treatment, two replications). DL-lactic acid (LA), added at 220 $\mathrm{mg} / \mathrm{kg}$, was also evaluated in an attempt to discover whether the lactic acid produced by these bacterial cultures is the cause of their effect on performance. The experimental treatments were: (1) control, (2) Probios, (3) Feed-Mate 68, (4) LA, (5) virginiamycin, (6) virginiamycin + Probios, (7) virginiamycin + Feed-Mate 68 and (8) virginiamycin + LA. The additives were included in the basal diet (table 1), which was fed ad libitum for 28 days in the same nursery in which trial 1 was conducted. Pigs were allotted to the treatments by initial weight (average $7 \mathrm{~kg}$ ) on the day of weaning.

Growing-Finishing Trial. A growing-finishing trial was conducted to evaluate the effect of $S$. faecium and lactobacillus probiotics in lincomycin-medicated diets on gain and feed efficiency. A $2 \times 3$ factorial arrangement of treatments was used, with lincomycin and probiotic source as the main effects. The 144 crossbred pigs (six pigs/treatment, four replications) were allotted to treatment by initial weight (average $34 \mathrm{~kg}$ ) and sex. The pigs were housed in outdoor pens

TABLE 1. COMPOSITION OF BASAL DIETS

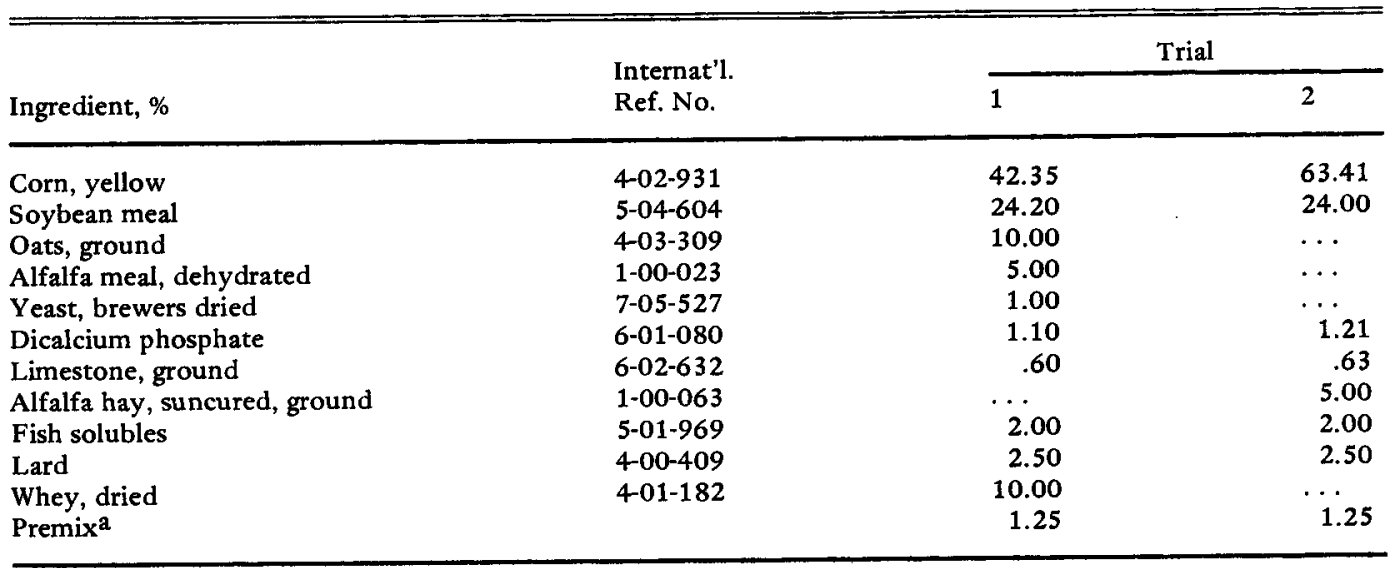

${ }^{a}$ Contained $.15 \%$ salt, $1 \%$ trace mineral mix, $1.0 \%$ vitamin premix in finely ground corn. Vitamin premix supplied (per kilogram diet): vitamin A, 4,394 IU; vitamin D, $426 \mathrm{IU}$; riboflavin, $3.3 \mathrm{mg}$; niacin, $21.9 \mathrm{mg}$; pantothenic acid, $4.5 \mathrm{mg}$; choline, $198 \mathrm{mg}$; vitamin $\mathrm{B}_{12}, 9.7$ micrograms. Trace mineral mix supplied (milligrams/kilogram): $\mathrm{Zn}, 200 ; \mathrm{Fe}, 100 ; \mathrm{Mn}, 55 ; \mathrm{Cu}, 11 ; \mathrm{Co}, 1.0 ; \mathrm{I}, 1.5$. 
TABLE 2. COMPOSITION OF BASAL DIETS

\begin{tabular}{|c|c|c|c|}
\hline \multirow[b]{2}{*}{ Ingredient, $\%$} & \multirow{2}{*}{$\begin{array}{l}\text { Internat'1. } \\
\text { Ref. No. }\end{array}$} & \multicolumn{2}{|c|}{ Diet } \\
\hline & & $14 \%$ & $16 \%$ \\
\hline Corn, ground & 4-02-931 & 79.25 & 73.65 \\
\hline Soybean meal & $5-04-604$ & 14.80 & 20.50 \\
\hline Alfalfa, suncured, ground & $1-00-063$ & 2.50 & 2.50 \\
\hline Dicalcium phosphate & $6-01-080$ & 1.15 & 1.00 \\
\hline Limestone, ground & $6-02-632$ & .80 & .85 \\
\hline Premix ${ }^{a}$ & & 1.50 & 1.50 \\
\hline
\end{tabular}

${ }^{a}$ Contained $.5 \%$ salt, $.075 \%$ trace mineral mix, $.925 \%$ vitamin mix with finely ground corn as a carrier. Vitamin premix supplied (per $\mathrm{kg}$ ) diet, 14\%: vita$\min \mathrm{A}, 2,214 \mathrm{IU}$; vitamin $\mathrm{D}, 436 \mathrm{IU}$; riboflavin, 2.2 $\mathrm{mg}$; niacin, $17.53 \mathrm{mg}$; pantothenic acid, $9.91 \mathrm{mg}$; choline, $220 \mathrm{mg}$; vitamin $\mathrm{B}_{12}, 24.26$ micrograms. Vitamin premix, $16 \%$ diet: that in $14 \%$ diet plus additional vitamin $A, 1,090 \mathrm{IU}$, vitamin $B_{12}, 24.26 \mathrm{mcg}$; (per $\mathrm{kg}$ ) diet. Trace mineral mix supplied $(\mathrm{mg} / \mathrm{kg}$ ) diet: $\mathrm{Zn}, 150 ; \mathrm{Fe}, 75 ; \mathrm{Mn}, 41.25 ; \mathrm{Cu}, 8.25$; $\mathrm{Co}, .75$; I, 1.125.

with a concrete apron and shelter, and fed ad libitum. The pigs received a $16 \%$ corn-soy diet until they reached approximately $57 \mathrm{~kg}$ and a $14 \%$ diet (table 2 ) thereafter until termination of the study. The treatments were: (1) control, (2) Probios $(500 \mathrm{mg} / \mathrm{kg}$ ), (3) Feed-Mate 68 (500 mg/kg), (4) lincomycin (110 mg/kg), (5) Probios + lincomycin and (6) Feed-Mate $68+$ lincomycin.
Data were analyzed by least-squares analysis of variance (Harvey, 1960). The orthogonal comparison for the main effects and interactions were performed by methods described by Snedecor and Cochran (1967).

\section{Results and Discussion}

Starter Trials. The effect of Probios in medicated diets on performance of young pigs is shown in table 3 . The addition of antibiotics, regardless of source, improved average daily gain $(A D G)$ and feed conversion $(F C)(P<.05)$. There were no significant differences between sources of antibiotics. There was a trend for improved ADG $(2.6 \%)$ and $\mathrm{FC}(3.6 \%)$ in pigs fed probiotics compared to nontreated animals. In the groups not receiving antibiotics, Probios improved ADG $4.5 \%$ and FC $7.2 \%$. When Probios was added to an ASP-250 or tylosinmedicated diet, a reduction in ADG was observed. Lincomycin produced better ADG when fed in combination with Probios than without (.307 versus $.265 \mathrm{~kg}$ ), suggesting a possible additive effect.

In the second trial (table 4), virginiamycin was evaluated in combination with Probios, Feed-Mate 68 and DL-lactic acid. The antibiotic effect on gain was not significant, but FC was improved slightly (2.68 versus 2.79 ). The addition of Probios improved ADG by $9.7 \%$ and FC by $21.4 \%$, whereas Feed-Mate 68 decreased

TABLE 3. EFFECT OF PROBIOS IN MEDICATED DIETS FOR YOUNG PIGSa

\begin{tabular}{|c|c|c|c|c|c|c|}
\hline \multirow[b]{2}{*}{ Item } & \multirow[b]{2}{*}{ Probios $b$} & \multicolumn{4}{|c|}{ Antibiotic source } & \multirow[b]{2}{*}{ Avg } \\
\hline & & None & ASP-250C & Tylosind & Lincomycine & \\
\hline ADG, kg & - & .223 & .294 & .269 & .265 & .263 \\
\hline Avgf & + & $\begin{array}{l}.233 \\
.228\end{array}$ & $\begin{array}{l}.289 \\
.291\end{array}$ & $\begin{array}{l}.253 \\
.261\end{array}$ & $\begin{array}{l}.307 \\
.286\end{array}$ & .270 \\
\hline $\begin{array}{l}\text { Feed to gain } \\
\text { ratio }\end{array}$ & - & 2.67 & 2.11 & 2.18 & 2.18 & 2.28 \\
\hline Avgf & + & $\begin{array}{l}2.49 \\
2.58\end{array}$ & $\begin{array}{l}2.10 \\
2.10\end{array}$ & $\begin{array}{l}2.28 \\
2.23\end{array}$ & $\begin{array}{l}1.94 \\
2.06\end{array}$ & 2.20 \\
\hline
\end{tabular}

\footnotetext{
${ }^{a} 192$ crossbred pigs ( 12 pigs treatment; two replications). Average initial weight, $7 \mathrm{~kg}$; length of study, 30 days.

${ }^{b}$ Probios (MuLabs Division, Pioneer Hybrid International) at $750 \mathrm{mg} / \mathrm{kg}$.

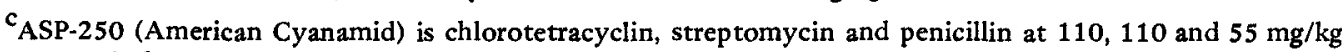
diet, respectively.

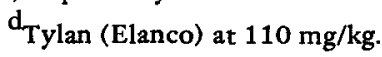

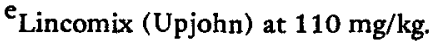

$f_{\text {Antibiotic effect }(}(P<.05)$.
} 
TABLE 4. EFFECT OF DRIED MICROBIAL CULTURES AND DL-LACTIC ACID IN MEDICATED DIETS FOR YOUNG PIGSa

\begin{tabular}{|c|c|c|c|c|c|c|}
\hline \multirow[b]{2}{*}{ Item } & \multirow[b]{2}{*}{ Antibiotic $b$} & \multicolumn{4}{|c|}{ Additive } & \multirow[b]{2}{*}{ Avg } \\
\hline & & None & Lactobacillic & S. Faecium $\mathrm{d}$ & Lactic acide & \\
\hline $\begin{array}{l}\text { ADG, kg } \\
\text { Avg }\end{array}$ & $\overline{+}$ & $\begin{array}{l}.145 \\
.145 \\
.145\end{array}$ & $\begin{array}{l}.150 \\
.168 \\
.159\end{array}$ & $\begin{array}{l}.141 \\
.127 \\
.134\end{array}$ & $\begin{array}{l}.158 \\
.122 \\
.145\end{array}$ & $\begin{array}{l}.151 \\
.141\end{array}$ \\
\hline $\begin{array}{l}\text { Feed to gain ratio } \\
\text { Avgf }\end{array}$ & + & $\begin{array}{l}3.49 \\
2.68 \\
3.09\end{array}$ & $\begin{array}{l}2.46 \\
2.40 \\
2.43\end{array}$ & $\begin{array}{l}2.88 \\
2.75 \\
2.82\end{array}$ & $\begin{array}{l}2.34 \\
2.87 \\
2.61\end{array}$ & $\begin{array}{l}2.79 \\
2.68\end{array}$ \\
\hline
\end{tabular}

${ }^{a} 224$ crossbred pigs (14 pigs/treatment; two replications). Average initial weight $7 \mathrm{~kg}$; length of study, 28 days.

${ }^{b}$ Virginiamycin (Smith Kline Corp) at $110 \mathrm{mg} / \mathrm{kg}$.

${ }^{\mathrm{C}}$ Probios (NuLabs) at $750 \mathrm{mg} / \mathrm{kg}$.

$\mathrm{d}_{\text {Feed-Mate }} 68$ (Anchor Labs) at $1,250 \mathrm{mg} / \mathrm{kg}$.

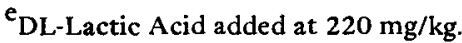

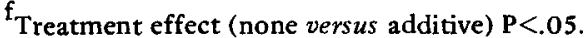

ADG. The difference in response between the first trial and second trial may have been partially related to diet. (The diet in the second trial was less complex.)

It has been suggested that the lactic acid produced as a metabolite during fermentation of a lactic acid-producing bacterial culture is the cause of any improvement in performance. The lactic acid treatment without virginiamycin produced the best feed conversion.
Growing-Finishing Trial. The results of the growing-finishing trial in which Feed-Mate 68 and Probios were fed in lincomycin-medicated diets are presented in table 5. Lincomycin was selected as the antibiotic because of the possible additive effect that was observed when it was fed in combination with probiotics in the starter diet in trial 1 . The lincomycin-medicated groups showed improved ADG $(\mathrm{P}<.05)$ and FC $(\mathrm{P}<.10)$ by comparison with the nonmedica-

TABLE 5. EFFECT OF STREPTOCOCCUS FAECIUM AND LACTOBACILLUS PROBIOTICS IN LINCOMYCIN MEDICATED DIETS ON PERFORMANCE OF GROWING-FINISHING SWINEa

\begin{tabular}{|c|c|c|c|c|c|}
\hline \multirow[b]{2}{*}{ Item } & \multirow[b]{2}{*}{ Lincomycin $b$} & \multicolumn{3}{|c|}{ Probiotic } & \multirow[b]{2}{*}{ Avg } \\
\hline & & None & Lactobacillic & S. Faecium $\mathrm{d}$ & \\
\hline $\begin{array}{l}\text { ADG, kg } \\
\text { Avg }\end{array}$ & + & $\begin{array}{l}.83 \\
.86 \\
.84\end{array}$ & $\begin{array}{l}.82 \\
.85 \\
.83\end{array}$ & $\begin{array}{l}.82 \\
.85 \\
.83\end{array}$ & $\begin{array}{l}.82 \\
.85^{\mathrm{e}}\end{array}$ \\
\hline $\begin{array}{l}\text { Feed to gain ratio } \\
\text { Avg }\end{array}$ & + & $\begin{array}{l}3.22 \\
3.12 \\
3.17\end{array}$ & $\begin{array}{l}3.22 \\
3.19 \\
3.20\end{array}$ & $\begin{array}{l}3.25 \\
3.14 \\
3.20\end{array}$ & $\begin{array}{l}3.23 \\
3.15^{f}\end{array}$ \\
\hline
\end{tabular}

\footnotetext{
${ }^{\mathrm{a}} 144$ crossbred pigs (six/treatment; four replications). Average initial weight, 34 kilograms.

${ }^{b}$ TUCO, Division of UpJohn Co.; added at $110 \mathrm{mg} / \mathrm{kg}$ diet.

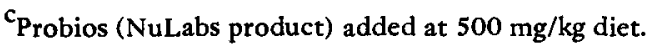

$\mathrm{d}_{\text {Feed-Mate }} 68$ (Anchor Labs) added at $500 \mathrm{mg} / \mathrm{kg}$ diet.

e Antibiotic effect $(P<.05)$.

$f_{\text {Antibiotic effect }(}(P<.10)$.
} 
ted groups. Although probiotics did not significantly affect performance, a slight reduction in ADG (.83 versus $.84 \mathrm{~kg})$ and FC (3.20 versus 3.17) was observed.

The data suggest that the two commercial probiotic products that were evaluated performed differently. It appears that the lactobacillus product is superior to the streptococcal product as an additive to pig starter diets. A greater response was observed with starting than with growing-finishing pigs.

Baird (1977) conducted three trials with feeder pigs with Probios added at $500 \mathrm{mg} / \mathrm{kg}$ and observed an improvement in ADG (10.8\%) and FC (7.2\%), a finding which is similar to the results observed here. Baird also observed an improvement in ADG (8.45\%) and FC (5.8\%) in growing-finishing pigs. Other researchers (Hines and Koch, 1971; Holden, 1976; Mahan and Newland, 1976; Cline et al., 1976) have observed no response when Probios was added to swine diets.

With the possibility of discontinued use of subtherapeutic levels of antibacterial agents, probiotics could be an alternative for microbial population control in the digestive tract of swine.

\section{Literature Cited}

Baird, D. M. 1977. Probiotics help boost feed efficiency. Feedstuffs 49(Sept.11):11.

Cline, T. R., D. Forsyth and M. P. Plumlee. 1976. Probios for starter and grower pigs. Purdue Swine Day Rep., p. 53.

Fuller, R. and B. E. Brooker. 1974. Lactobacilli which attach to the crop epithelium of the fowl. Amer. J. Clin. Nutr. 27:1305.

Hale, O. M. and G. L. Newton. 1979. Effects of a nonviable Lactobacillus species fermentation product on performance of pigs. J. Anim. Sci. 48:770.

Harvey, W. R. 1960. Least-squares analysis of data with unequal subclass numbers. USDA, ARS 20-8.

Herrick, J. B. 1972. Therapeutic nutrition using Lactobacillus species. Vet. Med. Small Anim. Clin. Nutr. $67: 1249$.

Hill, I. R., R. Kenworthy and P. Porter. 1970a. Studies of the effect of dietary lactobacilli on intestinal and urinary amines in pigs in relation to weaning and post-weaning diarrhea. Res. Vet. Sci. 11:320.

Hill, I. R., R. Kenworthy and P. Porter. 1970b. The effect of dietary lactobacilli on in vitro catabolic activities of the small intestinal microflora on newly weaned pigs. J. Med. Microbiol. 3:593.

Hines, R. H. and B. A. Koch. 1971. Response of growing and finishing swine to dietary source of Lactobacillus acidopbilus. Kansas Agr. Exp. Sta. Progr. Rep. 181:29,32.

Holden, P. J. 1976. The effect of commercial feed additives on the performance of early-weaned pigs. Proc. Internat'l. Pig Vet. Soc., p. AA5.

Mahan, D. C. and H. W. Newland. 1976. Short term effects of the addition of oats, bacterial cultures (Probiotic), and antibiotics to the diets of weaned pigs. Ohio Agr. Res. Bull., p. 35.

Metchnikoff, E. 1908. Prolongation of Life. G. P. Putnam and Sons, New York.

Mitchell, I. De G. and R. Kenworthy. 1976. Investigations on a metabolite from Lactobacillus bulgaricus which neutralizes the effect of enterotoxin from Escbericbia coli pathogenic for pigs. J. Appl. Bacteriol. 41:163.

Moon, H. W. 1975. An evaluation of the evidence of preventative or therapeutic effects of lactobacilli in enteric $E$. coli infection of swine. Amer. Feed Manufacturers Assoc. Nutr. Council, November, p. 42.

Muralidhara, K. S., G. G. Sheggeby, P. R. Elliker, D. C. England and W. E. Sandine. 1977. Effect of feeding lactobacilli on the coliform and lactobacillus flora of intestinal tissue and feces from piglets. J. Food Protection 40:288.

Parker, R. B. 1975. Applications of lactobacillus feeding in swine and other livestock. Amer. Feed Manufacturers Assoc. Nutr. Council, November, p. 38.

Porter, P. and R. Kenworthy. 1969. A study of intestinal and urinary amines in pigs in relation to weaning. Res. Vet. Sci. 10:440.

Shahani, K. M., J. R. Vakil and A. Kilara. 1976. Natural antibiotic activity of Lactobacillus acidophilus and bulgaricus. I. Cultured conditions for the production of antibiosis. J. Cultured Dairy Prod. 11:14.

Shahani, K. M., J. R. Vakil and A. Kilara. 1977. Natural antibiotic activity of Lactobacillus acidophilus and bulgaricus. II. Isolation of acidophilin from $L$. acidophilus. J. Cultured Dairy Prod. 12:8.

Snedecor, G. S. and S. G. Cochran. 1967. Statistical Methods (6th Ed.). The Iowa State University Press, Ames.

Tortuero, F. 1973. Influence of the implantation of lactobacillus acidopbilus in chicks on growth, feed conversion, malabsorption of fat syndrome and intestinal flora. Poul. Sci. 52:197.

White, R., G. Wenhen, G.A.M. Sharman, A. S. Jones, E.A.S. Rattray and I. McDonald. 1969. Stomach function in relation to a scour syndrome in the piglet. Brit. J. Nutr. $23: 847$. 